\title{
浮遊式波浪制御構造物の水槽実験結果について (2)
}

\author{
海洋科学技術センター続辰之介 \\ 浮田基 信
}

\section{1はじめに}

海洋構造物による海洋空間等の面的な利用拡大を図るためには、海洋構造物の大型化および大水深化が要求さ れるとともに、この構造物を外海の激しい気象、海象から保護するためにの波浪制御技術が不可欠である。従来 波浪制御構造物には防波提に代表される重力式防波提と浮遊式の浮消波堤がある。特に、後者は海水の流通を妨 げず、一時的な使用や地盤を選ばない特徽のほか、大水深での利用に適し比較的工費が安くなるなどの長所を有 するが、今までは波高が小さく、かつ波長の比較的短い内海や港湾等に適用が限られており、外海での適用は困 難であるとされていた。しかしながら、この浮遊式波浪制御構造物は技術的に適用が可能であれば、今後の海洋 空間の掘大を図るうえで重要な技術であるといえる。

そこで、本研究では外海に適用できる浮遊式波浪制御構造物の型式、基本形状を明らかにするため二次元规則 波実験においてポンツーン型を基本形状とする水平安定板付ポンツーン型が技術的および経済的にも充分可能性 があることを確認した。1) しかしながら、面的な波浪制御を行なうためには構造物を複数個係留設置する必要 があり、構造物間の開口部扔よび構造物端部からの回折波を含む消波特性、浮体運動による構造物間の相互の安 全性および係留などの位置保持の確認、さらには後背域に係留設置される大型海洋構造物との相互干涉等検討す ベき課題も多い。そこで、まず水平安定板付ポンツーン型浮消波堤を基本形とする構造物を複数個係留し、浮体 開口部および端部からの回折波を含む浮体後方の波浪状態および浮体の動摇特性並びに位置保持などを娭討する ため実験を中心とする研究を实施した。

なお、本研究は科学技術庁の昭和60年度科学技術振與調整費による「海洋構造物による海洋空間等の有効利用 に関する研究」のうち「浮遊式新型波浪制御構造物に関する研究」の成果をとりまとめたものである。

\section{$\underline{2 \text { 研究の概要 }}$}

2.1 䂙究の目標

海洋空䦐等の面的利用に用いられる大型の浮遊式海洋構造物を保護するための浮遊式波浪制御構造物は、ある 間隔で複数個係留されることが予想されるが、この場合の浮体後方の波浪状態を把握することは、大型浮游式海 洋構造物の構造、伱留系の設計や安全性を検討するうえで重要である。また、外海での波浪は方向性を持つので 斜め波中における浮体相互の挙動並びに安全性の確認も大切である。

以上の点を踏まえて、本研究の目標をつぎのようにする。

(1) 浮体開[部および端部からの回折波を含む波浪状態の把握

(2) 斜め波中における浮体相互の安全性の確認

(3) 浮体の動摇特性および係留張力の把握

2.2 研究の概要

上記の研究目標を検討するため、想定実機の1/40藉尺模型を用い、 规則波および不規則波湴びに正面波 $(x=90)$ および斜め波 $(x=60)$ を発生させ、浮遊式波浪制御構造物後方に扔引る数点での波浪計测、 浮体の動摇量および張力の計测、さらにビデオカメラによる浮体相 互の荤動等を钼祭することにする。

\section{3 研究实施内容抢よび結果}

\section{1 供試模型および実験水槽}

水槽实驓に用いた構造物模型は、ポンツーン型を基本形とする水 平安定板付ポンツーン型で想定笑機の1/40にしたものである。その 概略および主要目を图 1、表 1 に示す。实験水槽は運輸省船舶技術 研究所海洋構造物試験水槽で、その大きさは長さ40m、幅 $28 \mathrm{~m}$ であ る。また、実験時の水深は1.8mとし、これは实機スケールで72m 水 深に相当する。

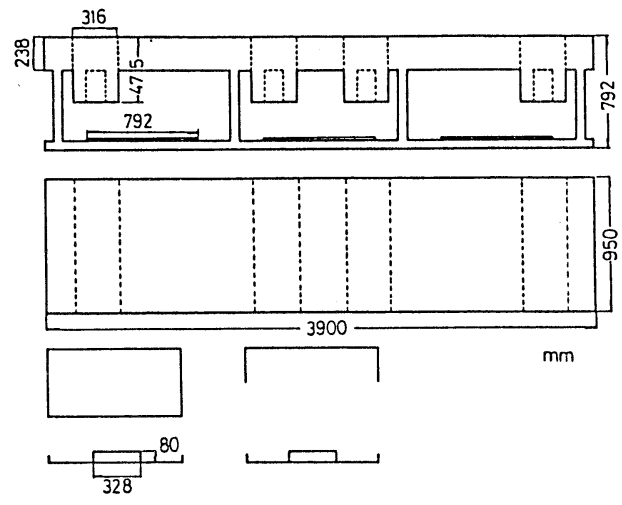

図 1 模型の概略図

表 1 模型の主要目

\begin{tabular}{|c|c|c|c|}
\hline 企. & 長 & L & $3.9 \mathrm{~m}$ \\
\hline 全 & 幅 & $\mathrm{B}$ & $0.95 \mathrm{~m}$ \\
\hline 商 & さ & D) & $0.792 \mathrm{~m}$ \\
\hline 唤 & 水 & d & $0.722 \mathrm{~m}$ \\
\hline 排 水 & 些 & $\nabla$ & $450 \mathrm{~kg}$ \\
\hline lleaving & 0)佔 & 厂咸扠 & $2.2 \mathrm{sec}$ \\
\hline Rolling & 0) $[15$ & 感监监 & $2.9 \mathrm{sec}$ \\
\hline
\end{tabular}




\section{2 計測項目}

構造物模型を 3 基係留設置し、以下の計測を行なった。

（1） 入射波および浮体後方の波浪

入射波は、サーボ式波高計を用い水槽側壁の造波装置近くにおいて計測した。また、浮体後方の波浪は計11点 で、容量式波高計を用いて計測した。

(2) 浮体の動摇量

中央模型の中心で6自由度動摇計測装置により浮体の動摇量を計測した。

(3) 係留張力

正面波では中央模型の波上側の両端部で、また、斜め波では波に対して横に展開された係留系の張力をリング ゲージで計測した。

表 2 実験で用いた規則波

3.3 波条件

(1) 規則波

本実験で使用した規則波を表 2 に示す。

(2) 不規則波

\begin{tabular}{|c|c|c|c|c|c|c|c|c|c|}
\hline & & 波 & 周 & 期 & 波 & & 高 & & \\
\hline 型周期 $(\mathrm{sec})$ & & 51.361 .58 & 81.902 .21 & 12.532 .85 & 波形こj配 & 0.02 & 0.03 & & 0.35 \\
\hline 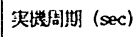 & 6.0 & 8.010 .0 & 12.014 .0 & 16.018 .0 & $5 \mathrm{c}: \mathrm{m}, 10 \mathrm{~cm}$ & 一定 & & & \\
\hline
\end{tabular}

不規則波はJONSWAP 型スペクトラムで、ここでは波高と波周期から求めた。2)

$\Phi(\omega)=\alpha \mathrm{H}^{2}{ }_{1 / 3} / \operatorname{Tp}^{4}(\omega / 2 \pi)^{5} \exp \left[-4 / 5(\operatorname{Tp} \omega / 2 \pi)^{-4}\right] \gamma^{\exp }\left[-(\operatorname{Tp} \omega / 2 \pi-1)^{2} / 2 \sigma^{2}\right] \cdots(3.1)$

ここで、 $\gamma=3.3, \quad \alpha=0.166, \quad \sigma=0.07,0.09, \mathrm{Tp}=1.1 \mathrm{~T}_{\mathrm{H} 1 / 3}$

（3.1）式により作成した不規則波の実測データを計測し、ゼロアップクロス法で求めた統計量を表3に示す。

表 3 実験で用いた不規則波の統計量

\begin{tabular}{|c|c|c|c|c|c|}
\hline \multicolumn{2}{|c|}{ 正 面 } & 波 & 2 & 3 & $4 \quad 5$ \\
\hline \multirow{2}{*}{ 姺型 } & $H_{1 / 3}$ & a & $\begin{array}{lll}23.7 & 22.5 & 24\end{array}$ & & $\begin{array}{lll}3.7 & 10.6 & 12.5\end{array}$ \\
\hline & Twean & $\sec$ & $\begin{array}{lll}1.94 & 1.39 & 1\end{array}$ & & $\begin{array}{llll}1.36 & 1.02 & 1.15\end{array}$ \\
\hline \multirow{2}{*}{ 央調 } & $H_{1 / 3}$ & $\mathrm{~m}$ & 㴖 9 & & 浩 $5 \mathrm{~m}$ \\
\hline & Tmean & $\sec$ & $\begin{array}{lll}12.3 & 8.8 & 9\end{array}$ & 9.9 & $\begin{array}{lll}8.6 & 6.5 & 7.3\end{array}$ \\
\hline
\end{tabular}

\begin{tabular}{|c|c|c|c|c|}
\hline \multicolumn{2}{|c|}{ 斜 め } & 波 & 2 & 6 \\
\hline \multirow{2}{*}{ 楼犁 } & $H_{1 / 3}$ & a & $\begin{array}{llll}25.6 & 22.6 & 25.2\end{array}$ & $\begin{array}{lll}16.6 & 12.7 & 14.7\end{array}$ \\
\hline & Trean & $s e c$ & $\begin{array}{lll}1.87 & 1.38 & 1.68\end{array}$ & $\begin{array}{lll}1.38 & 1.05 & 1.16\end{array}$ \\
\hline \multirow{2}{*}{ 実缷 } & $H_{1 / 3}$ & $\mathrm{~m}$ & 韭 $9 \mathrm{~m}$ & $5 \mathrm{~m}$ \\
\hline & Tmean $=$ & $\sec$ & $\begin{array}{lll}11.8 & 8.7 & 10.6\end{array}$ & $\begin{array}{lll}8.7 & 6.6\end{array}$ \\
\hline
\end{tabular}

\section{4 縦波中における水槽実験}

3.4 .1 規則波中での結果

(1) 消波特性

縦波中における波浪計測位置および係留ラインの張 り方を図 2, 圀3にそれぞれ示す。また、各点での波 高伝達率Kt $\left(=\mathrm{H}_{\mathrm{T}} / \mathrm{H}_{1 \mathrm{~N}}\right)$ について、横軸に実機想定での 入射周期、縦軸にKtを取って目 4-a c cに示す。これに よると、波長が長くなると波高伝達率Ktが悪くなる傾 向を示す。ここでは図示していないが、特に周期10秒 のH1.1およびH1.3でKtが 1 以上を示している。この原 因についてははっきりしないが、測点が浮体端部およ び開口部であり、かつ浮体の近傍であることを考える と、浮体からの反射波、あるいは浮体端部お上び開门 部からの回折波との干渉により波高が高くなったもの と考えられる。しかしながら、10秒のみこの現象がみ られることについての理由はわからない。また、入射 波の計測位置は水槽壁および浮体の近傍であるため、 それからの反射の影響を受けることが考えられるが、 計測デー夕を読みとる時には反射波の影響が出ない個 所を選んでいるので問題はないと思われる。いずれに しても、今後さらに検討する必要があろう。

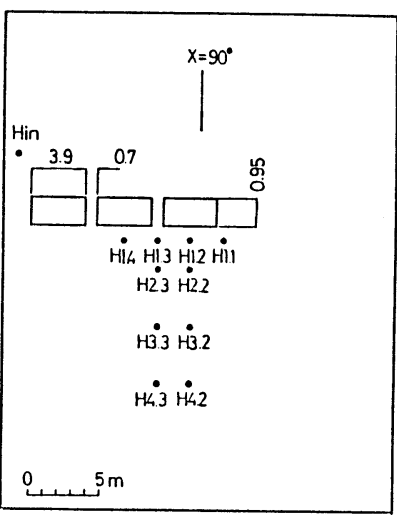

図 2 縦波中に扔引る波浪計测位置

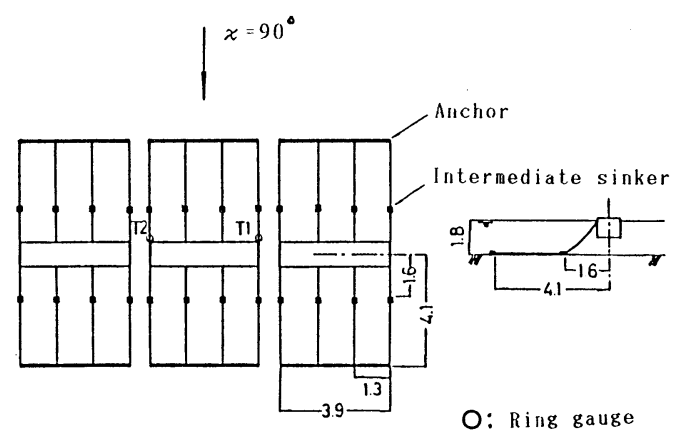

図 3 縦波中における係留ラインの張り方 
图3に示すよjな状態でのこの浮体の基本性能はおよそH1.4のKtのカーブで表される。これによると，T=10se

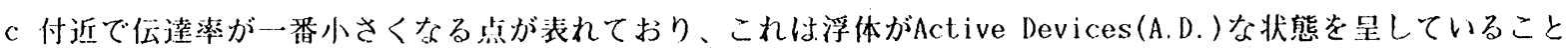
を示している。一方、その他の周期带では波長が長くなるに従い伝達率が高くなる頓向を呈するので、ここでは 浮体汃Passive Devices(P.D.) 芯状態で西ることがわかる。この上うに、入射波の波周期と浮体の運動との関係 を利用すれば伝達率を小さくすることがでさる。

本研究での紧求消波性能はT=14sec でKt=0.56であるが、この観点から挸則波の波高伝達率をみると、場所に よって筫なるが $\mathrm{T}=15 \mathrm{sec}$ 以上の長周期波になると全体的にKt:1近くになり、ほとんど消波効果がないことがわか る。浮体後方のある範围でKt=0.56 を满足する入射周期はT=10 12secで、目標值である いが、これは、浮体端部等からの回折波荙抑える手段を講しることによりKtはさらに下がるものと思われる。

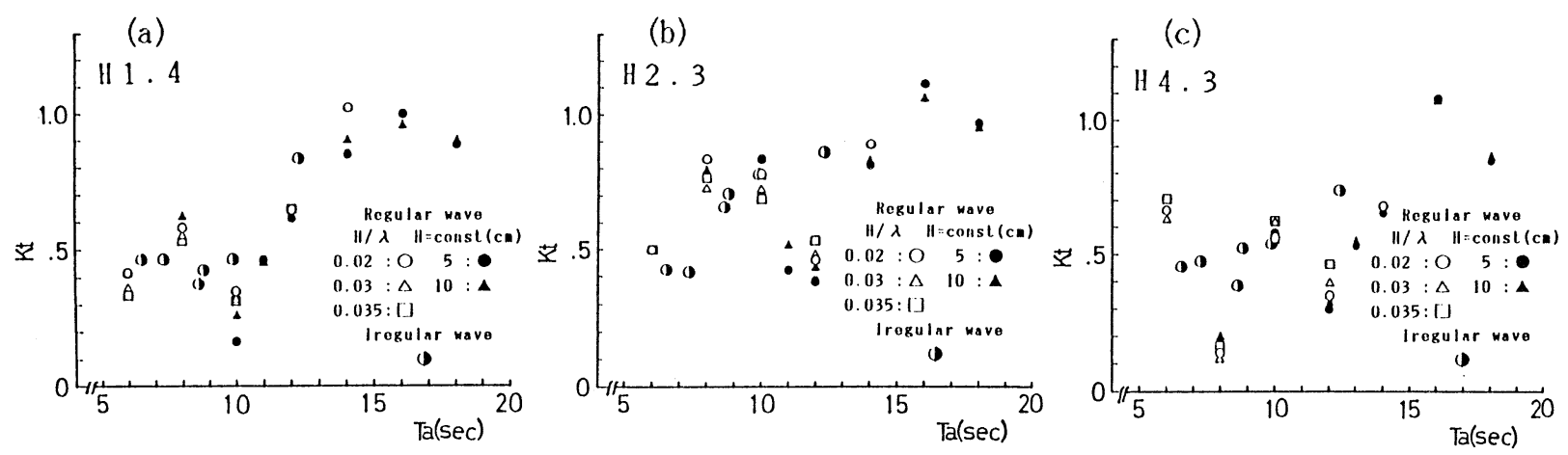

図 4 主な計測点における波高伝達率( Kt )

ところで、回折現象は避けられない現象で あり、これを把握しておくことは消波特性お よび配置などを考虑するさいに非常に重要で ある。そこで、ここでは近似解法として、半 無限防波提の場合を基準にして浮体端部およ び開口部からの回折波等の重ね合わせによる 方法で検討を行なった。

浮体後方の回折現象に影響を与之要因と しては入射波長、入射波们执よび開四部の間 隔など考えられる。ここで、入射波長を入、 開口部の閏隔をBとすると、今回の笑験では B/ $\lambda=0.08 \sim 0.50$ の範国であり、B注波長に 比べて非常に小さい場合である。このような 場合の入射波は開口部を点源として各方向に 一梯に広がり、波高分布は(3.2) 式で近似さ れる。3

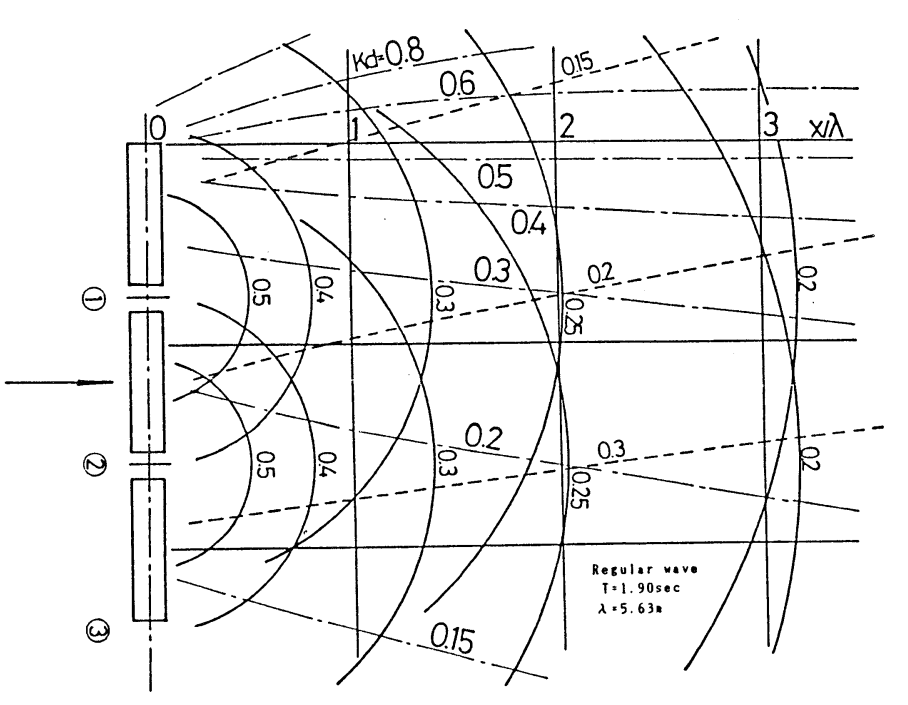

园 5 浮体後方における回折図の一例( $(\mathrm{T}=1.90 \mathrm{sec}, \lambda=5.63 \mathrm{~m})$

$$
\begin{aligned}
K d & =|\mathrm{F}(r, \theta)|=\pi / 2 \sqrt{\left.\kappa \mathrm{B}[\ln \kappa \mathrm{B} / 8+r]^{2}+\pi^{2} / 4\right]} \sqrt{\mathrm{B} / \pi r}-\cdots(3.2) \\
& \text { ここで、 } r=0.5772(\text { オイラーの定数) }
\end{aligned}
$$

図 5 は一例として $T=1.90 \mathrm{sec}$ の場合について、(3.2) 式を用いて浮体開口部からの波高分布を求め、さらに 浮体端部からの回折波は半無限防波堤による回折図から読み取り、これらを图示したものである。

今回計测した波浪は回折波、反射波および透過波など 表 4 各計測点における回折係数の実測值と推測値の比較 が重なり合ったものである。そこで、上述のような方法 で求めた回折図をもとに、浮体後方の波高分布が推测が きるかどうか検討したのが表 4である。これによると、 浮体後方の波高分仍は概ねこの方法で推测できそうであ るが、事例も少ないのでさらに娭討する必要がある。な お、斜め波の塂合は開口部の幅を $\mathrm{B}^{\prime}$ とすると $\mathrm{B} \sin \theta$ として同様に求めることができる。

(2) 連動特性

図6，7，8にHeave, Rol1, Sway についてそれぞれ示

\begin{tabular}{|c|c|c|c|c|}
\hline & \multicolumn{2}{|c|}{$\mathrm{T}=1.90 \mathrm{sec}$} & \multicolumn{2}{|c|}{$\mathrm{T}=1.26 \mathrm{sec}$} \\
\hline 部滑点 & 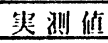 & 推汹值 & 春测佰 & 推测值 \\
\hline$\| 1.1$ & 0.70 & 0.83 & 0.83 & 0.76 \\
\hline 111.2 & 0.67 & 0.70 & 0.46 & 0.41 \\
\hline 111.3 & 0.63 & 0.74 & 0.63 & 0.47 \\
\hline$\| 1.4$ & 0.65 & 0.76 & 0.58 & 0.44 \\
\hline 112.2 & 0.67 & 0.64 & 0.25 & 0.42 \\
\hline 112.3 & 0.46 & 0.65 & 0.83 & 0.38 \\
\hline 113.2 & 0.83 & 0.57 & 0.50 & 0.41 \\
\hline 113.3 & 0.74 & 0.54 & 0.58 & 0.34 \\
\hline 114.2 & 0.78 & 0.55 & 0.58 & 0.40 \\
\hline 114.3 & 0.35 & 0.49 & 0.17 & 0.31 \\
\hline
\end{tabular}
す。Heaveの周有周期は実機スケールで14secである。 
また、Rol10固有周期は16sec 付近にみられるが、自由浮体での固有周期は18sec であるので、これは係留系や 他の蹅動との影響によるものであろう。Swayは12sec 前後で変動量が一番大きい。しかしながら、波を正面で受

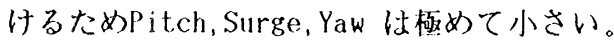

本浮遊式波浪制御構造物の消波原理は波周期と浮体理動との関係を利用するもので、この場合、浮体の上下運 動を消波させたい波哃期に同調させ、入射波と浮体の渾動によって発生する波との干涉により消波効果を発揮さ せようとするものである。したがって、今回もHeave の固有周期を消波させたい波周期と一致するように設定し たが、浮体の運動は他の運動との連成、渦、係留等の影響を受けるとともに三次元影響も大きいので、浮体の運 動によって消波効果を期待する型式はこれらを含めた莬討が必要である。

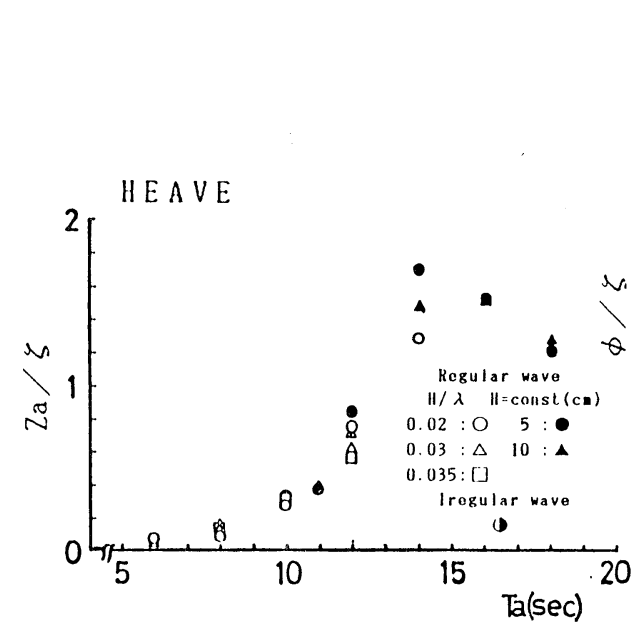

図 6 Heave 0 応答特性

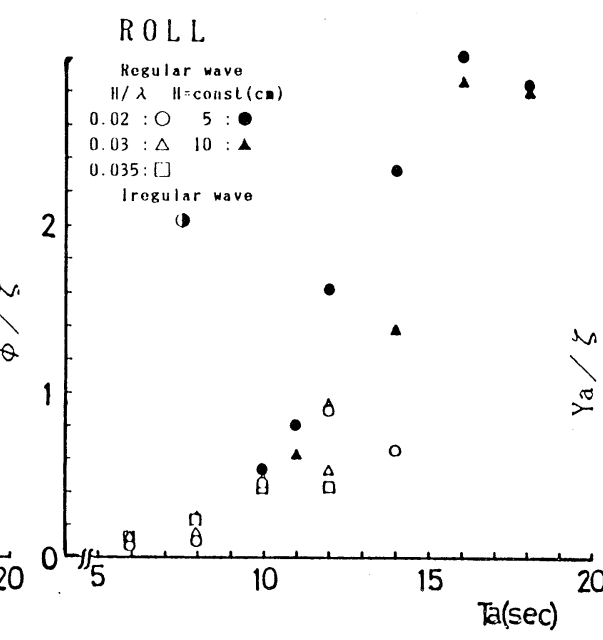

図 7 Rol10)応答特性

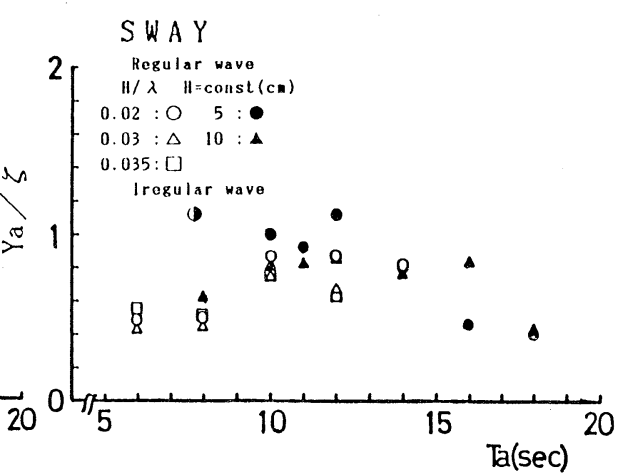

図 8 Swayの応答特性

（3）係留張力

図94T1（刚3参照）での各周期に対子る係留力 の最大傎を示めしたもので、14 sec 前後で最大張力 が表れている。これは浮体の跬動、特にHeave の影 䪪を受けたためであるう。

3.4 .2 不规划波中での結果

（1）消波特性

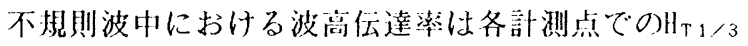
と入射波耐/3 示した。尔お、この埸命の波周期は平均周期（=2 $\left.\pi \mathrm{m}_{0} / \mathrm{m}_{1}\right)$ を用いている。

齐周期に刘するKtの変動はほぼ規則波のそれと同 じ倾向を示していることがわかる。夆た、热則波で 胃られたようなKtの極端次変動现象は見られないが、

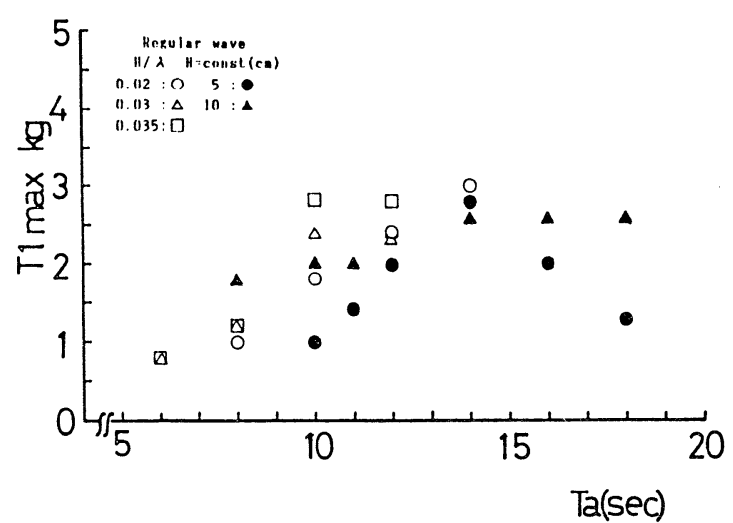

图 9 最大張力の応答特性

これは、浮体からの反射波などがあるものの次々と変化する波高や周期が来龍するため平均化されたためであろ う。つぎに平面的な伝達率の分布の一例について、图 10 に示守。この例では浮体後方で消波目標の0.56を满足 するが、これ以上の波周期になると充分な消波効果は期待できないが、浮体端部、開口部からの回折波も含告れ る点や、浮体の配置などを惹虑すれば伝達染はさらに下がることが予想される。

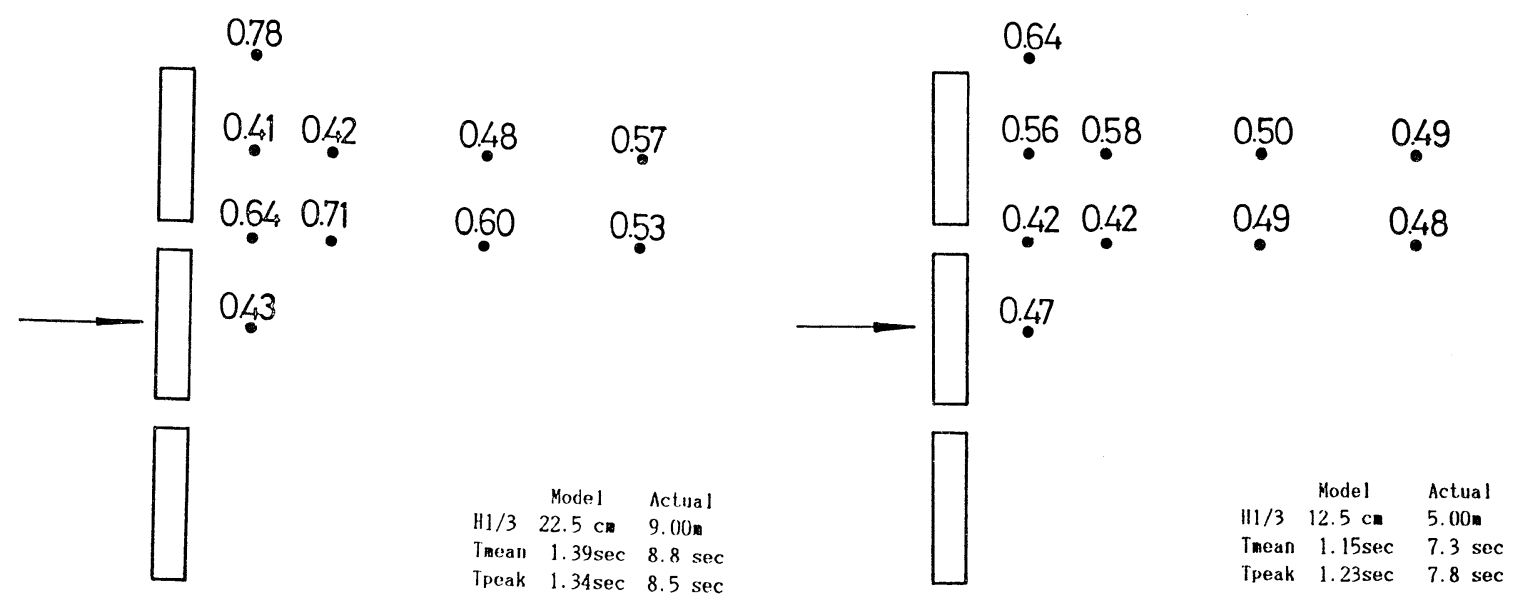


（2）運動特性および係留張力

運動特性の一例として図 11 に示すパワースベクトラム(Tpeak=2.30sec) を呈する入射波に対するHeave, Roll およびSwayの応答スペクトラムを目 12,13，14 にそれぞれ示す。これから、Heave とRol1はおおよそそれぞれの 固有周期に対応してピークが表れている。また、Swayでは波のスペクトラムピークに対応してピークがあらわれ ており、特に長周期側でエネルギー密度の高いピークがある。これは長周期運動を生したためである。この長周 期運動の生じる原因の一つとして、不規則波中で浮体に加わる長周期の変動漂流力があげられる。ここでは图示 していないが、張力のスペクトラムをみると、波のスペクトラムピークとSwayの長周期のピークに対応してピー クが表れている。このように浮体の長周期運動は係留系に多大去影響を与えていることがわかる。

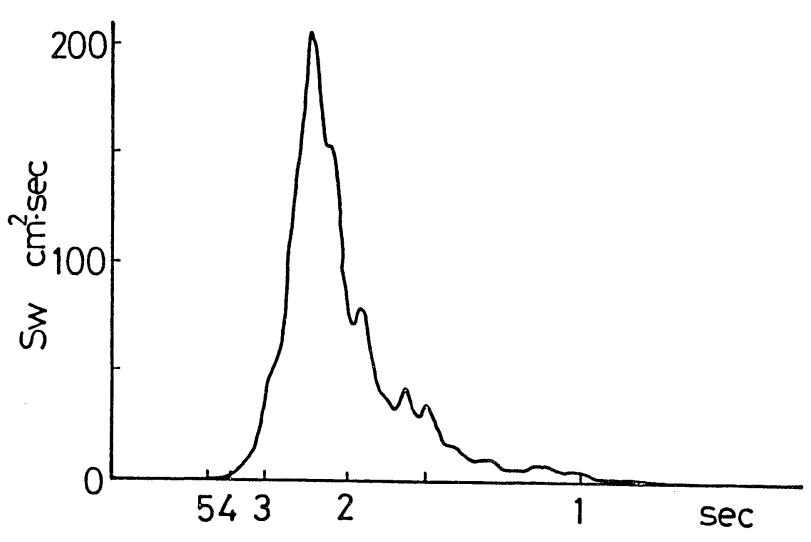

図 11 入射波のパワースペクトラム

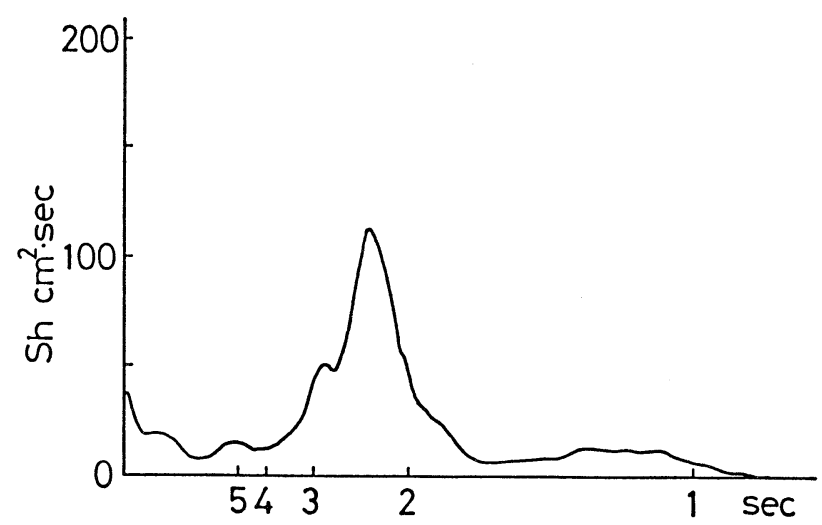

図 12 Heave の応答スペクトラム

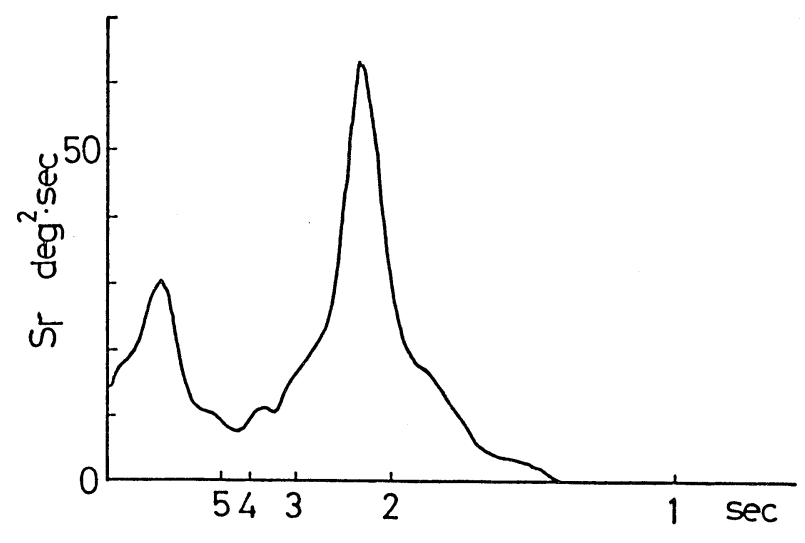

图 13 Rol10応答スペクトラム

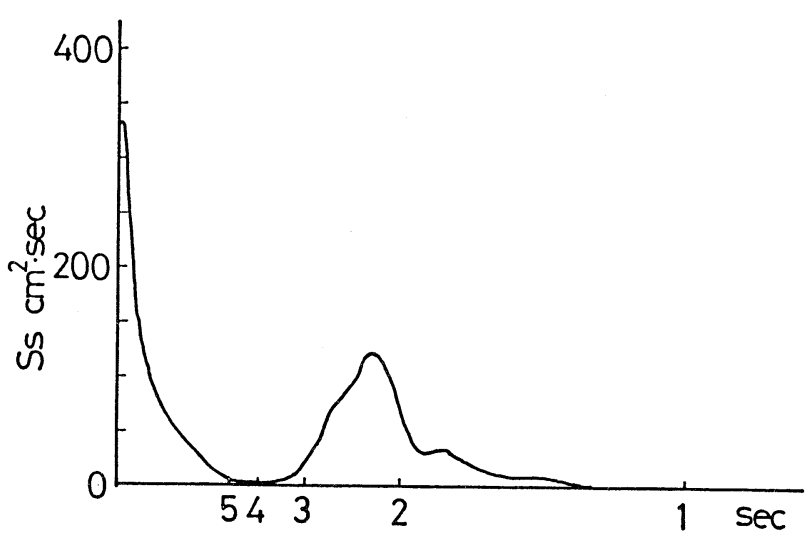

図 14 Swayの応答スペクトラム

\section{4 結 言}

以上、外海に適用できる浮遊式波浪制御構造物の開発を目標にして、二次元規則波実験で得た成果を基に、そ の力学的および形状の相似に留意しつつ、より実海域に近い条件での平面水槽実験を行なった。本報告は縦波中 での結果について述べたが、消波性能としてはT=10 12sec前後でほぼ0.56を满足する結果が得られた。また、浮 体端部や開口部からの回折波を含む浮体後方の波浪分布は、近似解法として浮体開口部からの波高分布と浮体端 部からの回折波は半無限防波是による回折図を描いてこれから読み取り、これらを重ね合わせて求める方法でお およそ推定できそうであるが、今後さらに検討する必要があろう。

一方、斜め波中でも諸特性把握のための実験を实施しており、この結果については別の機会で述べるつもりで あるが、特に斜め波で不規則波中では相互の浮体が運動するため衝乫の可能性があるが、今回の実験の範国内で は充分安全であることが確かめられた。

今後さらにこの浮遊式波浪制御構造物の後背域に係留される大型の浮游式海洋構造物との相互干渉等が苦えら れるので、構造物間の波浪状態や相互の運動について調べ総合的に検討する予定である。

\section{謝 辞}

本研究を進めるにあたり、有益なご意見を頂いた「海洋構造物による海洋空間等の有効利用に関する破究」の 研究推進委員会および建設技術ワーキンググループの各委員の皆様に心から謝意を表します。また、実験に際し て、实験水槽並びに計測器等にご配虑頂いた運輸省船舶技術研究所海洋開発工学部 高石敬史元部長並びに安滕 定雄現部長に謝意を表します。さらに、実験等に際していろいろとご協力頂いた海洋科学技術セン夕一・游洋開 
発研究部の工藤君明、宮崎武晃、堀田平、鴙尾幸久の各氏に、並びに東海大学海洋学部研究生吹田憲治、同卒業 研究生林秀明の両君に心からの謝意を表します。

参考文 献

1）続辰之介、浮田基信、石井進一、1985: 浮遊式波浪制御構造物の水槽実験結果について、第10回海洋開発 シンポジウム論文集、93-98.

2）小山建夫、藤野正隆、前田久明、1982：船体と海洋構造物の運動学、成山堂書店

3）岩垣雄一、棋木亨、1979：海岸工学、共立出版 